\title{
THE RUTGERS ORAL HISTORY ARCHIVES OF WORLD WAR II
}

\author{
BY G. KURT PIEHLER, REKHA GANDHI, AND DAVID TSANG HOU
}

G. Kurt Piehler is the director of Rutgers Oral History Archives of World War II project.

Rekha Gandhi (M.L.S.-SCILS '96) completed an independent study under Dr. Piehler's direction.

David Tsang Hou (RC '96) was a student in Dr. Piehler's undergraduate seminar, "Oral Histories of World War II."

I think for one thing it will indicate the great variety of experience[s] that our classmates and others at Rutgers had in World War II ... When we chat with one another and tell war stories ... that's just among the very few. But I think people will learn that our experiences were all over the world and covered a great range. The other thing that I hope will come out will be how people perceived that experience and what it did to them, what they learned from it. We all came from different backgrounds, and we came to Rutgers and we went in the service and it will be interesting to see how our backgrounds affected what happened to us.

In June 1994, Tom Kindre (RC'42) [TK] opened his interview with G. Kurt Piehler $[\mathrm{KP}]$ by explaining the goals that he hoped the Rutgers Oral History Archives of World War II project would accomplish. Initially conceived by Kindre and funded by the Rutgers College Class of 1942 and other graduated classes, the Oral History Archives records the memoirs of the World War II era alumni from Rutgers College and alumnae of the New Jersey College for Women (which became the Mabel Smith Douglass College in 1955). Sponsored by the Rutgers Department of History in cooperation with Rutgers University Library's Special Collections and University Archives, the project seeks to understand the broader political, military, social, and economic impact of the Second World War by using Rutgers and Douglass graduates as case studies. When completed, the Rutgers Oral History Archives of World War II will be an invaluable resource for documenting the history of a generation that came of age during the Great Depression and then helped overcome the threats of German Nazism, Japanese militarism, and Italian fascism.

From the beginning, the Rutgers Oral History Archives has sought to forge an intellectual collaboration between alumni, students, and faculty. Under- 


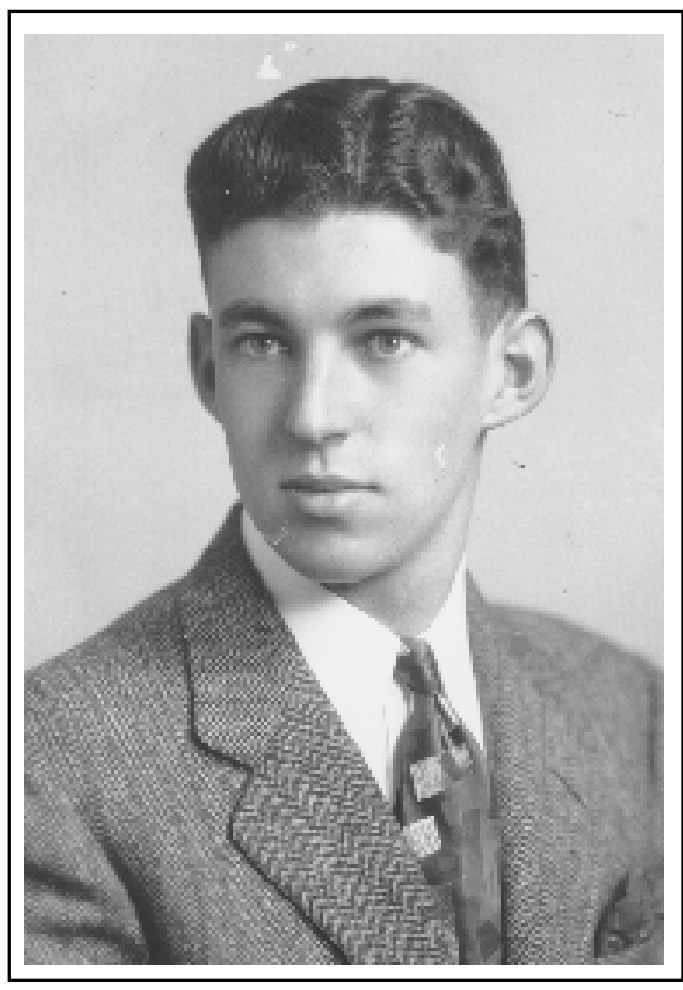

Figure 2.I Thomas A. Kindre photo in the Scarlet Letter, 1942, the Rutgers Yearbook. The entry for Kindre in the Scarlet Letter is: "Thomas A.

Kindre, Jr., a journalism major and a holder of a State scholarship, was graduated from Rayway High School. A commuter, he was membership chairman of the Commuters Club and a member of Philosophian. He was a Second Lieutenant in the ROTC and was enrolled in the CAA. Tom was also a member of the Journalism Club and wrote for a hobby." 
graduates, in conjunction with G. Kurt Piehler of Rutgers Department of History, conduct life-course interviews with alumni and alumnae who lived through the Second World War. These recorded interviews are transcribed and reviewed individually before final transcripts, together with tapes, are deposited in Special Collections and University Archives. In addition, all transcripts are available for immediate access through the Internet at http:// history.rutgers.edu/oralhistory/orlhom.htm.

Alumni have played a pivotal role in the creation of the Rutgers Oral History Archives of World War II. The initial idea for the project came from the efforts of Tom Kindre, president of the Rutgers College Class of 1942, who encouraged his classmates to write about their lives. In I993, Kindre approached Professors Rudolph Bell, then chair of Rutgers history department, and John Whiteclay Chambers II, then director of the Rutgers Center for Historical Analysis, with the idea of creating an oral history of his class. In return, Bell and Chambers convinced Kindre and the executive committee of the Class of 1942 to raise $\$ 100,000$ to begin the Rutgers Oral History Archives of World War II.

After becoming director of the Rutgers Oral History Archives in July I994, G. Kurt Piehler convinced the Class of 1942 to interview not only alumni who attended Rutgers before Pearl Harbor, but also to compare their experiences with those who attended Rutgers under the G.I. Bill. As a result, the Oral Archives targeted members of the Class of 1942 and 1949 for participation in the project and urged them to complete a lengthy preinterview survey that asked questions about their parents, childhood educations, Rutgers experience, wartime service, and postwar careers. Several Rutgers classes have assisted with the project, most notably the Classes of I940 and I943, by encouraging their classmates to participate in the archives and distributing preinterview surveys to them. Project staff have also attended alumni events and placed notices in university publications urging alumni to contribute their oral memoirs to the project. Since Rutgers College remained an all-male institution until I972, the project decided that it would be vital to interview alumnae of Douglass College, formerly known as the New Jersey College for Women. In 1996, Kurt Piehler encouraged Barbara Tomblin, then an adjunct lecturer at Rutgers and an independent scholar, to apply for and secure a grant from the New Jersey Historical Commission to interview Douglass alumnae.

In the first three years of the project's existence, over 200 alumni and alumnae have been interviewed. Over a dozen alumni have contributed diaries, letters, and documents that detail their World War II experiences. In June of 1994, Tom Kindre became one of the first individuals interviewed by Kurt Piehler for the Rutgers Oral History Archives. In addition, Kindre donated a copy of a diary he kept for several months while he served in the Italian theater. 
The following article will excerpt portions of Kindre's oral memoirs and his diaries. A complete version of his edited transcript can be found in the Special Collections and University Archives of Rutgers University Libraries and on the Rutgers history department's website at http://history.rutgers.edu/ oralhistory/kindre.htm. Like all individuals who have participated in the Rutgers Oral History Archives, Kindre reviewed and edited the completed transcript of his interview before it was deposited in the archives and placed on the Internet. Other than abridging it, no additional changes have been made to Kindre's oral memoirs. In transcribing Kindre's diary, we have sought to render it as close to the original as possible, thus retaining original punctuation, grammar, and spelling.

A scholarship student at Rutgers before he enlisted, this Rahway, New Jersey, native originally aspired to a career in journalism. During the war, Kindre served as a second lieutenant in an ordnance company for the 34th Division. After World War II, Kindre abandoned journalism for a successful career in public relations, retiring as senior vice president of Hill and Knowlton in I98I. In sharing his oral memoirs, Kindre had the hindsight of over one-half a century to place his childhood, college years, and wartime experiences into perspective. After relating his parents' and his own early life in Rahway, Kindre described his decision to select and attend Rutgers University:

KP: Why did you come to Rutgers, and had your mother wanted to send you to a Catholic college like St. Peter's or Fordham?

TK: My mother was a realist. At that time the Catholic high schools we knew had a poor reputation for scholarship. They weren't turning out people who were accredited for college and my mother knew that, even though she was a $[\mathrm{n}]$ ardent Catholic, organist, and choir director ... She never pressed the idea of a Catholic college. She left it entirely to me. I originally had been slated to be an engineer. All my uncles on my mother's side were engineers. My grandfather, my mother's father, was a stationary engineer. He ran an ice cream plant, and my uncle was in charge of an ice plant. They were sort of my role models. I was well on my way. At high school graduation, I won the Rensselaer Polytechnic Prize for the highest average in math and science. I was accepted by Stevens Institute. But something happened to me in my senior year in high school. I had got interested in writing, and I began to think it would ... be a very narrow thing for me to do to get into building a bridge or running a plant. I didn't want that. So I opted for a journalism career, and my mother and the rest of the family were totally amazed. Now why did I come to Rutgers? How I got to Rutgers is that the football coach in Rahway High School, Dave Bender, was an ardent Rutgers alumnus who lived here on campus. He lived in the old Faculty House on Queen's Campus, and he was a teacher at Rahway High School. When he found out that I was interested in journalism, Dave grabbed me and 
sat me down and said, "You've got to go to Rutgers. Rutgers has the best journalism school in the eastern United States." I had never heard of it so I came down here and looked at [it] and that's how it started, pretty accidental.

At Rutgers College, all students had to take two years of mandatory ROTC. In addition, Kindre learned how to fly through a special federal program aimed at cultivating a potential pool of pilots for the military and aviation industry. When asked about the Civil Pilot Training Program, Kindre reflected how the Army's adherence to bureaucratic order wasted his training.

KP: You mentioned on your survey that you had enrolled in the Civil Pilot Training Program. How did that come about? I know Rutgers had the program but is there a story of how you ended up getting a spot?

TK: I was a young romantic. I had on the walls of my study area photographs of Richard Halliburton, the popular adventure/travel writer, and Antoine de Saint Exupery, the French pilot and romantic novelist, and I've forgotten who else. Antoine de Saint Exupery probably had more influence on me. I read every one of his books about flying. He was a romantic himself and he romanticized flying. From Halliburton I got the idea of romantic adventure. I was very naive, unsophisticated, romantic. So, I wanted to get into flying and the Civil Pilot Training Program showed up and I was able to get my pilot's license for a total cost of $\$ 17$, which I paid for insurance. I couldn't pass it up. The problem, though, was that I wanted to get into the Air Corps, and I couldn't make it because I was in the ROTC program at Rutgers, got my degree, and was a second lieutenant infantry at graduation. There was no way I could transfer in grade. You couldn't do it in those days unless you had a congressman or someone to talk for you, and I didn't.

During his first three years at Rutgers, Kindre commuted to New Brunswick from his parents' home in Rahway. Commuters commonly missed out on a Rutgers social life that centered around athletics, fraternities, and a social calendar capped by dances and class balls. Eager to participate more fully as an undergraduate, Kindre recounted the great lengths he went in order to experience "college life" at Rutgers:

KP: You were a commuter, and then the last year you lived on campus. One of the divisions on campus was between commuters and those who lived on campus. What could you add to that since you've experienced both?

TK: Commuters were felt to be a lower grade of people and in fact my friends and I-there were four of us, three members of my class and one sophomore-finally got together enough money to spend our senior year on campus because we wanted to overcome that problem of being looked down upon. Prior to that we also started a 
Commuters Club to do something for all these people who were just running back and forth on trains and didn't have time for a social life... It was a problem because you really couldn't take the time to get into activities. I went out for fencing, for example, and I loved it. But I didn't have the time in my commuting schedule. I had to drop it. I went out for Targum, the newspaper, and worked for a while on that, but again with the train schedule and everything I just couldn't do it.

KP: So you would take the train down from Rahway?

TK: Yes.

KP: And did you work during the school year?

TK: The first three years I worked summers as a salesman for a coal company, door to door, selling coal contracts for the coming winter. In my senior year, to fund the cost of actually living on campus and paying for part of an apartment, I worked for a while at nights in a meat packing plant in Newark, and at the same time I was in the Civil Pilot Training Program. So my schedule was to go to Newark at 9:00 at night. I got finished around 5:30 or 6:00 [in the morning] and rushed to Hadley Airport for a dawn flight. They had a 7:00

[a.m.] flight so people could work in a flying lesson before they went to their 8:00 classes. I would work at night, take the flight, and then I'd sleep all day in my classes.

Until Pearl Harbor, many Rutgers students paid little attention to the war. But prominent speakers advocating intervention and nonintervention did speak at student convocations and before student organizations. Some students even formed and joined organizations favoring or opposing intervention. In the case of Kindre, the approach of war in 1940 lead to his fateful decision to join the optional advanced ROTC training.

TK: Well, I was a pacifist and that's the direction I was heading: to serve those two years I had to, because it's a land-grant college and then get out ... But toward the end of my sophomore year, ... I was beginning to see that Hitler had to be stopped, and I saw that we were going to be in the war. I had no doubt of that because of the way the conflagration was building in Europe. Since I was ... going to be inducted as a private anyway, why not go for a commission? So I did. I went into advanced ROTC. I even had to get a special dispensation because I hadn't made my decision before the deadline. I got into summer camp.... and then into the last two years of ROTC.

KP: So, when you say you were a pacifist, how did this view of war arise? When did you see the change? What was your view of ... being a pacifist?...

TK: That started in high school. I remember writing essays about the stupidity of war. I don't recall whether there was a specific event that changed it. It might have been the invasion of Poland. It was 
something that finally kicked it over the edge, and I saw it was inevitable. "I'm going to be in the war," I thought, "and I don't want to be a private when I could be a second lieutenant."

... [In] our senior year, we had a lot of work to do, but on the other hand, once Pearl Harbor occurred we were in a sort of never-never land. My classmate, Dick Kleiner, coined the term, "We were the class of forty-tude." Because we didn't know what was going to happen to us. So for five months we lived in this strange situation where we were trying to pursue a normal academic life at the same time the world was exploding. I don't remember getting together in bull sessions and saying, "What's going to happen?" "Where are we going to go?" We were just busy.

A romantic by his own admission, Kindre remained naive about the risk entailed by war and the high casualties that junior infantry officers faced in combat. During his interview, Kindre recounted his resistance to efforts to transfer him to another branch:

TK: Well, I didn't know what it entailed. I found out later. It entailed danger. Second lieutenant infantry was arguably the most dangerous rank in the military because you were a platoon leader.

You were the guy who said follow me and I never thought of things like that. When I got overseas as a replacement I went with a group of 90 other infantry second lieutenants. We got to know one another pretty well on the boat going over, and I found out toward the end of the war when I met a couple of them and we went through the rosters that there were four of us still living out of that 90. I was so dumb when I got into a replacement depot in Algeria and the major called me in and he had my personnel record in front of him and he said, "It says here that you have a private pilot's license and we have an opening for a job as an Assistant Headquarters Commandant to a Corps Commander, and part of your job would be spotting locations for the Corps to move.". . It sounded like a very cushy job, and my answer to him was-I can still hear it reverberating in my head-_"Thank you, Sir, but I've come this far and I'd like to see what's going on up at the front." It sounds like something out of the Dawn Patrol. I was so dumb.

KP: And this coming from someone who originally was a pacifist. You were a pacifist.

TK: Yes.

KP: You were leaning towards pacifism.

TK: Yes. But it was this romanticism for flying that I apparently was beginning [to] attach to the war. Then eventually I was saved from myself at another replacement depot where they looked at my record and saw that I had taken the motor maintenance course, and they had an opening for an Ordnance Officer. There weren't any Ordnance Officers and I was second best, so I got that assignment and I went through the war as an Ordnance Officer. 
War brought far-reaching changes to the men of Rutgers College. Marriages were postponed or hastened, careers put on hold, and almost all the men of Rutgers enlisted in some branch of the armed services. Some of the changes brought by the Second World War proved subtle, but just as significant. For instance, most of those who attended Rutgers prior to the Second World War came from families of modest means and seldom traveled outside of New Jersey. Except for a trip to a soapbox derby in Ohio, Kindre himself had never been to another region of the United States. After reporting for duty in June 1942, Kindre traveled south to complete advanced training. This emigration from New Jersey not only improved his skills as an officer, but also opened his eyes to Jim Crow segregation for the first time:

KP: Where did you first have your training? You got through ROTC so where was your first assignment after graduation?

TK: Camp Croft, South Carolina. It was a Replacement Depot. I was there for only a matter of a few weeks, I guess, when along came this Motor Maintenance School assignment. Fate, fate, oh boy, fate was everything. I was standing in the day room by the door to the adjutant's office when he came out and said, "I got five for Fort Benning Motor Maintenance School. Let's see, you, you, you, you, and you." I was standing there so I got sent to three months of Motor Maintenance School at Fort Benning and then after Fort Benning I was assigned to Fort Jackson, South Carolina, to the thenassembling I00th Division. So, all my experiences were in the South. KP: So, you were sent to the South as a young second lieutenant? What was your immediate reaction to the South?

TK: Well, I had a rude awakening because when I saw what was happening to black people in the South I was really upset. I never had that kind of experience in Rahway. There were four black students at Rahway High School, and everyone treated them well. There was no segregation. Nobody looked down on them. Now suddenly, down here in the South I could see all the separate but equal paraphernalia and I was very much disturbed by it. I sought out people, intelligent people in the community, whom I could talk to about it. I struck up an acquaintance with a radio newscaster, and he spent long hours telling me about the separate but equal doctrine, but I couldn't accept it.

KP: He was trying to justify it?

TK: He was trying to justify it. Well, he was in the middle somewhere. He was telling me why it was and how it worked and so on. And of course it was always justified on the basis that it was best for the Negroes, as they were called at that time. Because it kept them separate from the whites, and therefore, out of trouble. But I didn't see it that way and I got into a fracas in the barracks with a guy from South Carolina. 
KP: How did it begin?

TK: I don't remember how it started. There was a discussion, and it ended up in a lot of nastiness, just short of fisticuffs. But he threw everything at me, all the old cliches like "do you want your sister to marry one," and all that. I abhorred it. I just was very angry about it.

One of the potential limitations of oral history as a historical source is the understandable tendency of some individuals to romanticize the past or forget the unpleasant. In the popular memory, the Second World War has been commemorated as the "good war" that united Americans around a common cause. In recounting his last few weeks before departing overseas, Kindre recounted the unwillingness of some his fellow servicemen to leave the United States.

KP: What do you remember about war-time New Brunswick and Rutgers? Did you go back to see the college or see the town?

TK: No, I didn't have time. At Shenango before I got to Camp Kilmer the discipline was so bad that I signed myself out and came home for a weekend. Nobody knew or cared and I came home and it was at that point that I got engaged. I came home to spend time with my girlfriend and when I got to Kilmer I was able to see her once. She was at NJC, now Douglass ... We weren't there very long ... When I got to Shenango, I was put in charge of a train [of] 90 second lieutenants and 600 men because I was the senior second lieutenant. Some officer came up and said, "Here are your orders, lieutenant, you've got 600 people under your control here." I opened the orders and I knew we were going to Kilmer. So, at Kilmer I was still responsible for those enlisted men and the thing I remember most is guys going AWOL because they knew they were heading overseas. They would take off in every direction and the MPs would drag them back. I had one guy that did it three times in the few days we were at Kilmer. Each time I gave him company punishment, which was to dig a hole six feet deep and then I would put a fork from the mess hall in the hole and cover it up and then [have] him cover the whole thing up and then ask, "Now which way is the fork pointing?" He didn't know so he'd have to dig it up again. That was standard company punishment at the time.

Kindre discussed his reaction to North Africa and Italy at length in his interview and also in his diary. His fascination with different cultures was not shared by all American servicemen. In fact, Kindre expressed dismay over how some GIs mistreated the Arab inhabitants of North Africa.

KP: And since you say you were very romantic, what were you expecting to find, especially in North Africa? What was your image of North Africa or Arabs?

TK: Sort of exotic, I guess, and a lot of that was borne out along the way although a lot of other things were borne out that I hadn't thought about, too. It, . . . let me go back for a moment to the blacks 
in the South. I think a major thing I learned in the war that I had never really experienced was the inhumanity to people, how people were treated inhumanly everywhere by various groups of people. This was a new experience for me. In Africa, I learned that among certain American units, they would use the Arabs for target practice.

KP: Where?

TK: In Algeria. Guys would brag about it. They'd see some Arabs come across the hill and they would dare each other. Let's see if you can knock one off, and they would shoot these Arabs. They were a subrace. They weren't human. The Arabs got even though. The American GIs drove jeeps around with the windshield down because of the hot climate and the Arabs strung piano wire across the roads and decapitated a lot of them.

KP: So, this shooting, ... the target practice, when would ...

TK: Target practice on live human beings. This would take place in the ... evening ...

KP: How common do you think this was? Was this just an isolated incident?

TK: I don't know how widespread it was, and I don't know whether it was related to a particular type of American soldier or to somebody from a particular part of the country. I didn't have direct experience, but I heard about it.

KP: Enough to leave an impression.

TK: Yes,

KP: But it wasn't isolated?

TK: No. It happened enough so that people talked about it.

KP: And the stringing of piano wire? How often, how frequent was that?

TK: I have no idea. But I did hear it happen from time to time and then, of course, when that began to happen, they put the windshields up. They didn't ride around with the windshields down anymore. At the time I was in North Africa you were told, "Don't drive around with the windshield down in a jeep at night."

KP: Because of the wire?

TK: Yes, but the reason they were doing that was because GIs were using them as target practice. That was a terrible thing...

KP: No, this is the first I've ever heard.

TK: It was what I came to call the gook syndrome, ... which is that some people are lesser than others.

KP: But, they were not the enemy, the Arabs.

TK: No, they were not the enemy. 
Kindre remained uncertain of his role as a replacement until his first assignment upon reaching North Africa. After an uncomfortable trip from Oran to Tabarka, Tunsia, Kindre served the remainder of the war with the 34th Division.

TK: ... Now to answer your question about Africa. After going cross-country ... we arrived at Tabarka, Tunisia-that's were I was assigned to the 34th Division as a replacement ordnance officer. I joined the 34th in Tunisia and had a couple of interesting experiences that summer. They assigned me to a salvage patrol to go down in the desert and police up the wreckage of allied airplanes that had been shot down. I took ... twelve six-by-six trucks and I had a jeep. A sergeant was the driver and we just headed south over those terrible roads. At one point, in the middle of the desert we passed a Roman ruin with stone columns.

KP: This must have really fit your romantic notions.

TK: And then we got where we were going, which was an oasis, called Gafsa. There was a full moon. It was an absolutely gorgeous place surrounded by all this bleak desert. Here were springs and palm trees and a little hotel run by a Frenchman. I took my whole crew for every meal into the hotel and we ordered Boef Stuk (beef steak) for every meal. It was undoubtedly horse, but didn't matter. It was a fun experience. And then I had a terrible experience coming back because I had, just in that short time, grown accustomed to the unit I was assigned to and when we came back from the salvage operation to where our unit had been, there was an empty hillside. They were gone. I was in shock. We found that the 34th had been moved into Oran in preparation for the invasion of Italy. I rejoined them, but then I got hepatitis. There was a faulty yellow fever vaccine that had been sent overseas and a lot of people got hepatitis from it.

Most participants in war have neither the inclination nor the time to keep a diary; personal papers of all kinds are often lost in the flux of war. Kindre, however, was different. He kept a war diary that faithfully records names, places, and numbers and offers an invaluable supplement to his oral recollections. It focuses on the essential, but often mundane, aspects of daily life in the army: meals eaten, duties performed, movies viewed, and friends met. A terse, descriptive writer, he can also elaborate on his experiences in the Army and perceptions of other cultures he encountered in North Africa and Italy. In his July I9, I 943, almost haiku-like entry, he recounted the high price war inflicted on individual lives and recorded the story of a French master sergeant separated from his family in Paris.

Gafsa—moonlight and palm trees.

American cemetery—sgt. and gvt.—only English speaking soldiers in or near town. Job— to beautify cemetery-lonely. No one 
to report convoy in to. Bivouac under stars and full moon. I,056 A, 800 Germans buried in cemetery. While in American cemetery, heard wailing-Arab wedding.

Wailing, moonlight, white crosses. Rows of crosses -

I dog tag and a name plate.

800 Arabs killed in fighting at Gafsa.

French garrison-picked up French soldier, carted him around in jeep, looking for dump-no luck.

Senegalese in barracks-big, black, shining teeth, red fez. Beat tom-toms (gas drums) at night.

Frenchmaster-sgt.

Born in China, home in Paris, 4 years in England, graduated Cambridge '36, in army 7 yrs. ('43). Married 3 mo. before war, son $2 \mathrm{I} / 2$ yrs. old. Wife \& child now in Paris, hasn't heard from them in 3 yrs. Wife Belgian. Father-in-law now in a German work camp.

Was in prison camp in Austria, near Vienna. (8 mo.) British bombing, Germans moved captured British lorries into area to stop it. X and a pal hid in lorry, were driven to occupied France, discovered, locked in R.R. station pending arrival of Gestapo.Escaped thru a window-found 2 gendarmes' bicycles_rode 175 miles in Paris. Paris not yet occupied, but very little food available. 2 I /2 - yrs old child asked him for bread. "How could I tell him there was no bread?" "How could a child understand that?" "Things of that sort I cannot forget." Deep hatred of French for Germans.

Pale blue eyes, open face, soft voice. (Robert Donat Jr. Hilary)

Austrian prison camp-I small meal/day.—pottage. work from 5AM till 9PM.

"It will take 15 years for the world to straighten out."

Hotel Nouvel—beefsteak, tomatoes, omlette, vino.

Proprietor-pleasant little man with cigar.

Herd of hundreds of camels on road crowded around dirty little stream of water.

Arab funeral- deceased falls face up or face down.

French post office-WAAC operaters._-"allo, GA-BES"

"allo, TAY-BES' SAH”

Departing WAACS say goodbye—voluble tears, talk, singing, etc.

NAMEONVEHICLES

STEP 'N FETCH IT - 4 T WRECKER

MISS CARRIAGE—4 T

MOUSEMEAT—4 T WRECKER 


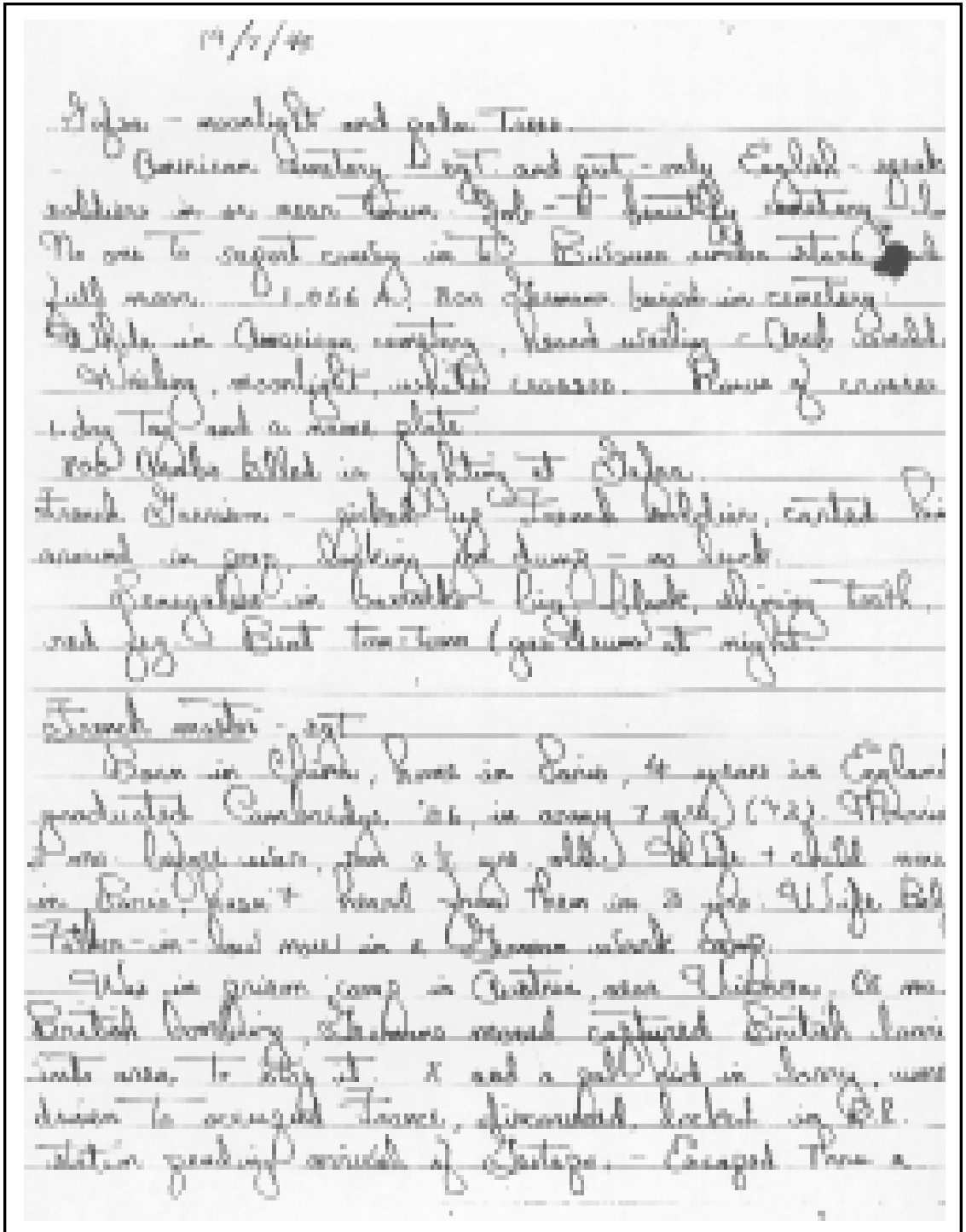

Figure 2.2 July I9, 1943 entry in Kindre's diary 
Illness and hospital confinement prevented Kindre from joining his division's invasion of Salerno. While hospitalized, Kindre took the time to record the hospital's library collection containing such works as Steinbeck's TortillaFlat, Forester's Beat to Quarters, and paperbacks from the Pocket Reader and Companion series, now historically known as the "Penguin Pockets." After rejoining his unit in Italy, Kindre recounted his days in Italy and the events he witnessed, rumors heard, and rhythms of daily life in a war zone.

Oct. II [1943]— saw Naples for Ist time—with Cook \& Williams.

Met Teissier Road choked with families moving back into city.-

Entire household on one cart. Population standing in line for water.

Germans destroyed water \& sewage systems. Stories of destruction of Naples untrue. Much damage in outskirts factory and port district, but city hardly touched. Germans left time-bomb in Post Office, killed scores of people. Bomb in basement-wire running to curb.Truck backed against wire. Vesuvius smoking on way home.

Nov. I5 [1943]—3 more packages_-Inez, Kieseckers, Bill and Ruth. Candy, cookies, too much of everything. - Went to Piedmonte today. Palace of duke.-_"Duca Laurenzana" Palace commands view of city, must have been beautiful once. Square courtyard in middle, with fountain. Italian workmen said Germans had used bldg. as a hq., destroyed everything possible when they left. Set mines under the walls, blew out parts of walls and roof. Main hall (about $60 \times 40^{\prime}$ ). Thirty large portraits all around hall, above windows - dukes who have lived in bldg. Room, adjoining main hall—music room and library. I piano with smashed keyboard. Germans burned most before they left. I bookcase left-contained several volumes of history of Rome and many bound volumes of a French weekly publication "L'Illustration, Journal Universal" pub. Paris. The issues ranged from 1843 to I856.-General news, literature, science, etc. Issues of 1849 depicted scenes of California showing life of miners. Old workman told me to take copy of "Julius Caesar ___ in Latin, pub. Naples, I84I. Took it.

JAN. 9 [1944]

Received word we are to move up. Advance party went up and found no suitable area, so will stay here for few days. San Vittore taken yesterday at great cost in men. Fight for Cassino still rages. Several good rumors these days. I. Starting next mo. Div. will send I000 men home/month. 2. Div, will be out of Italy by Ist of mo. 3 . (Direct through channels from Gen. Ryder's pastry cook)—German officials sat in on Cairo conference, decided to surrender to Americans. 34th will be relieved by 88th, go to England, make invasion. There will be token resistance for 2 weeks, then victory. Eisenhower has left for 2 nd front. Willkie criticized by Pravda, Russian paper, for talk about Finland, Balkan States' territorial integrity. New soldier vote bill being introduced. Varga girl supported by well-known clergymen. 
Walked up mt. to chop wood. pasture half way up and olive trees. Beautiful view of valley. Purple sunset. Had toasted raisin bread in tent tonight.

JAN. I3 [1944]

All artillery seems to have moved out from vicinity of our area. Has apparently moved further up to shell Cassino. Order came thru today that we will not fire on planes unless actually attacked. The sky is full of them and the ack-ack opens up occasionally. Our boys on the 50's all have itchy trigger fingers. They jump to their guns every time the ack-ack starts, just hoping that Jerry will come down to strafe, so they can get in some shots at him.

Took a shower this afternoon. Weather is warm, almost spring-like, during day. Except for the planes, all is peaceful. Since the artillery moved up the birds have come back and they flit merrily thru our olive grove in the mornings. It sounds wonderful to hear even one bird chirp in the silence of the morning. It's a sound of peace-a deceitful sound.

Casualties in the taking of (Cenavo?) must have been heavy. I40 replacements have arrived in the Division.

36th Division is back in action on our left flank.

Today's rumor-45th Div., which was recently pulled back from our right flank into rest area and relieved by the French, has been recalled to front because French were unable to hold positions against Jerry counter-attacks.

Jeeps are coming in today from the infantry to have litter racks welded on them. I33's area, on rt. flank of division is so rugged that it's almost impossible to remove wounded to rear. Engineers are building trails just wide enough for a jeep. We're welding a rack over the hood to hold two litters. Frenchy, from I35, said a 240-1b man was badly wounded last night in I33 area, and it took I 2 men 9 hours to carry him to rear.

Although often in harm's way, Kindre never had to fire a shot in anger as a result of his assignment as an ordnance officer. In his oral memoir, he recounted vividly the experience of encountering the first German war dead and realizing their essential humanity.

TK: Yes, I guess I had a number of vivid memories. I think probably one of them would have been the first time I came upon dead German soldiers. There'd been rapid advance by our division so the graves registration people hadn't had time to catch up. We moved into a new area and I was walking out to establish a location for a latrine, and here was a little mound and two bodies, two Germans who had been in a machine gun emplacement. I remember being particularly impressed by the fact that there were letters. The guy had been reading a letter from home. There was a little book with names and addresses in it. That was the first time I had seen dead 
Germans. I'd seen a lot of live German prisoners in Africa because we went by one of the pens where they had thousands of them when Rommel's Army was broken up, but I hadn't seen any dead ones before, so I remember that rather vividly.

The Italian campaign had been urged on the Allies by Winston Churchill as a way to take advantage of the "soft underbelly" of Europe. Although Mussolini's fascist government quickly collapsed after the invasion of Naples, German troops poured into southern Italy and took advantage of the scores of geographical barriers that limited offensive action. For American and other Allied troops, warfare in the Italian land turned into a brutal war of attrition with gains on the battlefield coming at great cost.

January 27, 1944

Went with Kiefer and Harold Branum on reconnaissance of new area across mt., between San Vittore and San Pietro. Road from Venafro goes up in a gradual climb for several miles—cut into rock of steep mountainside.-View is beautiful. Snow-topped mountains in distance, Venafro growing smaller and smaller, peacefully checkered valley below look as if ugliness of war had never touched it. Road crosses mt., then long descent along mt. side overlooking Liri Valley. The valley is completely pock-marked. Area from San Pietro to San Vittore is most scarred of any I have seen in Italy.-Groves of shattered olive trees—only splintered trunks left standing.

San Pietro and San Vittore virtually destroyed. This is the first battlefield I have seen worthy to be compared with the horror pictures of France in World War I.

War disrupted the lives of scores of civilians caught up in the conflict. In one of his most poignant diary entries, Kindre described the story of an orphan who ended up living with his unit for a time.

Feb. 3 [1944]

Barker and Wendt to rest center. Ferrara back from rest center, brought Johnnie with him. Johnnie is I5. He lived with his mother and father in France. His mother was Spanish, his father AmericanMexican. His mother died, and he and father escaped from France when Jerries invaded. They managed to get to Casablanca and then worked their way to Tunisia. Johnnie says his father joined the 9th Div. Johnnie went along with him. His father was killed in the Sicilian invasion, Johnnie returned to Africa, wandered around, was picked up by I5I FA., made Salerno landing with them, was wounded, sent back to Africa. After leaving hospital he hitchhiked back to Italy. Our boys found him in Naples. Johnny is intelligent, speaks English, German, French, and Italian, will stay with us for awhile.

Although not a front-line soldier, Kindre remained close enough to the enemy to face mortality on more than one occasion. Once, Kindre almost fell victim to a German artillery barrage, but for intervention by fate. 
KP: You mentioned that you hadn't been fired upon directly, but you had had several close calls with artillery.

TK: Oh, yes. That's true. I remember one time in front of Monte Cassino. The 34th Division was part of a force that was trying to take Monte Cassino. We were scouting an area for the ordnance company, facing directly toward the monastery. I mean, we were standing in a field that sloped down to the river from the other side of which rose the hill the monastery was on. There was a ruined farmhouse, I remember vividly, with one stone wall standing and I started to walk toward the stone wall and maybe out of instinct or what, I don't know, I walked to the left of it. At the very moment I did that, an $88 \mathrm{~mm}$. shell exploded on the other side of the wall, just a couple of feet from me. I would surely have had it had I walked on the other side of the wall. There were many little instances like that. One night we were pounded by artillery. It was all around us. I slept through most of it and my fellow officers were up all night. They were all prowling around and I slept.

In two diary entries from February, Kindre recounted the incessant shelling during the struggle to capture Monte Cassino. The entry from February 5, 1944, described how the fog of war lead him into harm's way.

Feb. 5 [1944]

Morning-Went up ahead with Capt. Moeglein and Jendro to look for a new area. Went thru Cervaro. Town is well wrecked. Near the center of town GRS has set up-a large canvas-enclosed squaregot a glimpse thru the corner of the blood and gore. Went thru town and out onto the Cervaro-Highway 6 road, where we were supposed to pick an area. This area is on the very doorstep of Cassino. We could see every building in Cassino just a short way across the valley, with the monastery perched high above-a lethal, well-loaded item of historic interest. Hundreds of lives have already been lost because of its historic value.

We had left the jeep and were walking around, surveying the prospective area with misgivings, wondering at the strange silence over Cassino, lying mute and deadly under its pall of smoke, when suddenly Jerry began to throw them in. We hit the ground and watched them burst on the far edge of the field toward Cervaro and in the town itself. During a lull we decided we were in an unhealthy place, so hopped in the jeep and took off toward Highway 6, but were stopped by MP's and a sign which said, "No vehicles beyond this point-road under fire." So we turned around and streaked back toward Cervaro. The shelling had stopped temporarily, and we saw new rubble piles as we went thru town. The shells began to whistle in again before we were out of town. We jumped and hit the dirt, while they came in, but couldn't stay there forever, so grabbed the jeep again and finally got thru the town, with the shells pounding in behind us. Met the division Red Cross girls outside of town, shooed them back. 
Feb. 9 [1944]

Push on Cassino still going, bloody inch by bloody inch. Practically every night now brings nothing but broken sleep. At irregular intervals during the night Jerry shells (w--?) in with a load, melancholy shriek and burst with a loud, "KA-WOOF." It's too cold and wet to get out of bed, so there's nothing to do but lie there and listen. Each whistle seems to last IO yrs., and nerves are taut almost to the breaking point, until suddenly the KA-WOOF! The tent is still standing, no shrapnel had gone thru it, so nerves relax and wait for the next one.

Hit the jackpot in mail today-finally, after a week.

Evening-played rummy with Swanee and Capt. Jackson.

Interviews with subordinates and enlisted personnel can offer important insights into the leadership abilities of senior commanders. Kindre's responsibilities in ordnance allowed him to make some informed judgments regarding the generals who led his division. At the same time, Kindre remained a perceptive observer of the backgrounds and personalities of the men who served in his units:

KP: In terms of the ordnance, what were your ... unit's responsibilities during the war, and did they change during the Italian campaign, the part that you were in?

TK: Well, the ordnance company was charged with supplying vehicles and armaments for the division and repairing. Repair, replacement and so on. So we had constant traffic and vehicles that were brought into us for repair, and we were constantly ordering weapons and ammunition. I remember the first shells we got with proximity fuses. They had radar elements in the shells so that the shell could perceive the altitude above the ground, and they could be set to go off at any altitude. That was a big advance. I remember when that happened. I was in supply. I was a supply officer and I had six parts trucks. Each with a parts man specialist. We carried most of the automotive parts. We had some interesting experiences. The first division commander that we had was a wild man. His name was Ryder, General [Charles W.] Ryder, and he wanted to be up where the action was so he kept getting his jeeps shot up. He kept bring [ing] them in for repair, you know or salvage. Most of them were just salvage, and we knew that whenever we heard from division headquarters that General Ryder has been out again with the recon troops, we'd have work to do.

KP: What happened to him over the course of the war? How long did he stay with the division?

TK: He did not make it to the end. He was replaced by General [Charles L.] Bolte. He was a more quiet man, not a wild man. So, our wrecker people had some interesting experiences. Our wrecker crews had to go up and reclaim these vehicles in areas that were 
under fire sometimes, and they were interesting guys, the wreckers. They were big and husky, very husky and devil-may-care.

KP: Had many of them driven tow trucks during the war?

TK: Oh, sure.

KP: Did you find that your unit personnel matched up? Had they done this as civilians?

TK: Pretty much, yes. It was a National Guard unit, and they had been mechanics or parts men or something like that pretty much before the war. I was thinking of this one wrecker driver that I knew. His name was (Willie Williams) and... I was responsible for him, along with the others. I had to get him out of trouble quite frequently. He was a big guy, and he liked to have a good time, and he had a short temper. I remember one time I had to go into Naples and get him out of a whorehouse because he had shot the place up.

KP: Quite literally?

TK: With a Tommy gun. He stood in the middle of this place and shot all the mirrors off the walls. The MPs had picked him up and I had to go vouch for him and take him out under my recognizance.

There was a lot of that kind of thing.

Military service had a far reaching impact on those who served. Some servicemen and women would be scarred by physical and mental disabilities for a lifetime. Others, like Kindre, gained incomparable experiences at an early age through working and directing large organizations. There are more subtle, yet lifelong, repercussions that remained as a result of military service during the Second World War. Kindre's speech would be transformed by the war. As he recalled:

TK: I didn't know about it, and strangely enough, when I came home none of my friends, even my girlfriend, didn't say anything about it, but I was on a business trip one time after the war riding on an airplane and my seatmate turned out to be a professor of linguistics who said that he could determine within a hundred miles where anybody came from. I said, "Okay, where have I come from?" and he picked an area that included the southern part of Minnesota and the eastern 50 miles or so of South Dakota. "You're from that area." I said, "No way. I was born in New Jersey and lived in New Jersey all my life." He said, "Well you couldn't. That's impossible." "During the war," he said, "where were you?" And I said, "I was with the 34th Division." " Ah, Minnesota, Iowa, South Dakota National Guard Division.” My speech had been permanently affected.

Oral histories can provide useful information to discern the cultural differences that existed among the Army, Navy, Army Air Corps, Marine Corps, and Coast Guard services: Kindre recounted the sharp differences that existed between National Guard and regular army division: 
KP: This was a National Guard unit and what did you think of the nature of the leadership of the National Guardsmen?

TK: A lot of problems in the National Guard. My company commander of our company had his brother as shop foreman and there were at least three other sets of brothers within our company, lots of prior relationships. Lots of people who were now in the command structure higher than the people they had worked for back home. I remember a guy saying one time, "Well, I can't do anything to him. When I get home he's my boss. I can't discipline him." There were many problems like that. Another one that I remember vividly was the infantry lieutenant colonel who had goofed up badly in one of the major battles and was relieved from duty but because he was a friend of someone high in the division, maybe the division commander, I don't know. They made him the division special service officer. The guy should have been court martialed. Instead he was made the division special service officer and also, talk about injustice, he was put on the division court martial board where he became one of the most bloodthirsty advocates of severe sentences. Things like that happened in the National Guard divisions.

The Second World War remained a war of global proportions. In his diary, Kindre expressed fascination with the multinational complexion of the armies fighting in Italy as recorded by his observations made on February I3, 1944.

Feb. I3, [1944]

Went back to 79th Ord. today with Swanee and (_oway?) Back along highway 6. In the valley between San Vittore and the highway the British and Gurkhas are bivouacked—packed in tightly. Thousands of Gurkhas wandering around-dark, black-eyed, fierce, handsome, beturbanned fighters. Highway 6 itself was choked with dust as column after column of heavy British recovery vehicles moved up. More traffic than Route 25 thru Rahway. Everywhere back along the highway are units of every description-American, British, Indian—artillery, service units, QM, shower units, tank units;- - everyone working.

And along both sides of the road, hundreds of strands of telephone wire, along the ground, thru the trees. At every crossroads \& turn, hundreds of unit signs.

Despite the mud, danger, and responsibilities, there remained much that Kindre enjoyed about Italy. As he recalled in his interview, the Italians showed him a different cultural life-style from one he experienced in New Jersey.

KP: You had experiences in northern Africa. What about Italy? I know in your travels Rome must have been an incredible, romantic place. What were your experiences with Italians as you were moving up the boot of Italy. Did your views of Italy change? 
TK: It's a strange thing to say, I know, but I felt more at home in Italy than I had in the United States growing up. Well, that's a difficult thing to say, but I say it because the Italian people so impressed me with their warm earthiness, real earthy friendliness which is something I had not encountered in the United States. It was a new feeling for me. It was a new kind of culture. I never thought that was possible and I loved them. They were all great.

KP: In other words you were struck by the sort of aloofness of New Jersey?

TK: I wasn't at the time but ... In contrast, when I got to Italy I thought, my God there are people who live like this. They're open, friendly, earthy, honest and those were mostly the peasants, I guess, that I encountered. I didn't know anybody in high places, but I really loved them. I thought they were great.

KP: Did you often eat at the homes of the Italians you encountered? TK: Yes, when we move[d] into a new town there was a lot of give and take. I remember one little town that we moved into. Their lighting system was dead. They hadn't had their lights for a long time, and we had these M5 generators in the ordnance company which were big enough to light a town like that so we'd hook it up. Turn on the lights in the town and the mayor would come, and we would talk to him and then everybody would get invited for spaghetti and vino at somebody's house and oh, yeah, great fun. And one time we were invited, we were traveling and we just stopped for a meal and this family just came and invited us in. When I say us, I mean the group of four or five officers. And they served us tremendous piles of spaghetti, and we didn't want to hurt the woman's feelings, but we couldn't begin to eat all of it. You know it's incredible when I think back on it now, what we did. We opened the bottom drawer in her bureau when she was out of the room, and we took all the spaghetti that we couldn't eat, and we shoved it in the bureau drawer and closed it and went on our way and said thank you.

War transformed units. The 34th Division lost much of its "National Guard" element as high casualties mounted. Individuals, often away from their hometowns for the first time, responded to newfound freedoms in ways that shattered traditional mores.

TK: Their morale was very bad and the constant turnover brought a lot of changes in the cultural composition of the division. My company, the ordnance company, remained as it was because we didn't have causalities, but the infantry units had great turnover so that the National Guard aspect of it, after a while, was gone. It was a more cosmopolitan kind of organization, and I think that that put a burden on the National Guard officers that they hadn't had before. There was a medical man in the 34th Division who was the first who identified what came to be called battle fatigue. He wrote a paper on 
it which I've got. I could give you a copy of it. And he had observed two kinds of battle fatigue: that which comes from long experience at battle and that which comes from no experiences. At the very beginning, the first battle, people were getting a kind of battle fatigue because of the shock of combat. He identified the symptoms of these two different phenomena and wrote extensively about it, and it was through him that the Army came to recognize that there was such a thing as battle fatigue, that a man just couldn't go on anymore, couldn't cope after a while...

KP: Now you mentioned that you had one run-in with someone who did some shooting ... Did you have any other experiences in terms of discipline especially with MPs in terms of your men or was that the one notable [instance]? Because there was resentment of GIs towards the MPs.

TK: Toward the MPs, oh yes. I know that. I had a few others like that in Italy who shot things up in town from time to time. I can't remember another specific instance like the one I mentioned, but they hated the MPs because the MPs were inhibiting their fun. They were back in Naples to have a great time and that meant just letting off steam totally, and the MPs were rotten people. Discipline, I had another guy in Italy whom I had to discipline constantly because he couldn't stay away from the prostitutes, and he'd come in with a case of clap every other week or so, and I had to do something to try to keep him from getting out of the area so I'd restrict him to quarters and make him dig a hole or make him do some duty like that. And a couple weeks later he'd be back again, and he'd show up on the medical record again. This went on the whole campaign like that.

KP: Given your most recent story, what were your observations of the soldiers in terms of sex? Was going abroad a liberating experience from say the restrictions at home?

TK: No question about that. It was totally liberating. Most of the people that I was with in the military were from small towns and fairly restricted upbringing. Everybody knew everybody else and you couldn't get into too much trouble. So here they were in a foreign country with license, they felt, to do just about anything they wanted to and I think the sexual mores were very open. The problem was one of disease that we had to try to control because venereal disease was rampant, but that didn't stop some people at all. This leads me to another thought about the Italian people ... I felt such sorrow for the Italian people in one way and that is because of the prostitutes. There were so many of them and of course the coming of the war and the foreign troops and the shortages of food and virtually everything turned so many, many into prostitution. Our guys would occasionally bring one along to a dance or something and I remember talking with some of them and they could sense, I think, that I didn't approve of their lifestyle, and they would begin to 
defend themselves. We had some conversations and it became apparent to me that this was a life saving step that they'd taken. They had nothing to eat. The family had nothing to eat and so they entered into prostitution, and they didn't necessarily all feel very good about it.

KP: What was your attitude as a junior officer? What was your sense of the Army attitude toward prostitution? The official and maybe the unofficial?

TK: The official position was strictly a defensive one in terms of disease control. "Stay away from these women because you'll get sick, and we can't have you getting sick because we need you to work here in the Army. We need you to do your job.” That was pretty much it. There was no moral judgment. The unofficial position was do whatever you want to do as long as you don't have a problem, and that was true of the officers as well as everybody else. Nobody was told not to deal with prostitutes-only in terms of keeping disease free.

Kindre sought relief from the stress of duty and the battlefield by taking advantage of movies periodically shown in rear areas. His diary includes a list of movies he viewed, and scattered through the text are comments regarding some of his favorites. It is clear that Kindre saw his share of "war movies" including "Wake Island" and "Commandos Strike at Dawn." In addition, Kindre found time to view several movies destined to become classics, including "Casablanca" and "The Philadelphia Story." As Kindre's diary records clearly show, and to the strength of the project's goals, the war experience intermingled with all aspects of American society. This instance highlights popular entertainment and culture. As these little vignettes of good old American leisure perpetuating overseas show, even in a time of war, there remained reasons to celebrate. Kindre clearly enjoyed the camaraderie of his fellow officers in the support unit as reflected in his February 22, 1944, entry:

FEB. 22 [1944]

Jendro found his brother in a rear echelon outfit, brought him to co. area, fell from jeep, smashed his face. Mac called in Co. Hq. at I IOO, told me my promotion had come through. It is effective from

February 6. Started wearing silver bars this afternoon. Evening- $\$ 22$ worth of gin came in today from Special Service for co. officers, so I bought the works for my promotion party: Kiefer, Mac, and I got a head start on everyone else, immediately after supper; during the course of the evening we made speeches, swung from the ridge-pole, dragged Finch and Hammer over and got them drunk. Everyone who came into the tent was rolled on the ground and had gin poured down his gullet (including the Colonel). We all got pretty well knocked around in the course of the evening. 
Even when away from the battle zone, one could not escape the cost and impact of the war. Kindre tried his best to alleviate the burden but despite his attempts, the war remained actively in the background. Among his efforts to put the war on hold were seeking others from the banks of the old Raritan and going out on the town.

March 30, 1944

Morning — went with Porter in Ford to 5th Army Hq.- saw Walt Shultise, who works in Ammo Sect. Walt and I discussed plans for a Rutgers reunion in Italy. He has already written to Old Queen's on the idea and received encouragement. We're going to meet again in a few days and start sending out letter

Evening - got dressed up tonight for first time in 7 mos. Dressed in borrowed greens. I went with Col. Hmrbk., Moeglein, Capt. Jones to Allied Officers Club on hill overlooking Naples. Beautiful club, finished in marble. All-around balcony upstairs with an extra bar. The orchestra was Italian and excellent. Every imaginable uniform present-American, British, French officers, nurses, WAC's, ATS, Red Cross girls, Canadians, Scotsmen dancing in kilts. Drinks were fairly good-gin and cognac.

APRIL 6 [1944]

Stood in line at San Carlo Opera House from I200 to I500.

Got 2 officers' tickets, 8 EM. Went back to parking lot, discovered someone had stolen key from my jeep. Steeped in righteous anger, I searched the streets for another jeep with a key. But alas, in vain! Stopped to haggle with an Italian storekeeper and brought an inlaid wooden cigarette box. Returned to lot, crossed wires, and went home.

APRIL 9 [1944]

Buona Pasqua. Wore greens to mass at 0900 in seminary chapel at Div. Hq. After mass, stopped in for a few drinks with boys at Div. Hq.-Stewart Halverson, Gallager, Joseph.

Back from church, changed clothes, went to the 6th to see about ship this afternoon.

Stopped jeep on way back, turned off motor and sat quietly, listening to the bird songs, smelling the blossoms, feeling the warmth of the earth permeate my soul, wondering how people who possessed such intrinsic beauties could kill each other....

Picked Langer up at I300. Berg drove CR again. We stood around the racetrack with our luggage until I800, admist confusion. Finally went by truck to dock. Rain almost all afternoon. Boarded the Elizabeth Stanton about 1900. She is a transport ship-type C-3. Moved out into the harbor just before dark. 
APRIL I I [I944]

We put out to sea about 0630 . The weather is clear, bright, warm, only a slight swell on the sea. There are I0 ships in our convoy and 2 destroyer escorts. Ours is the flagship. Passed Sorrento and Capri, and then-out of sight of land.

The food on board is wonderful—nothing dehydrated, all real. Fresh bread baked every day. The mess hall holds only 46 officers, so there are 3 sittings. About I50 officers aboard. Everyone on board, except Langer, myself, and a handful of others is going home on rotation. There is no wild exuberance, strangely enough, on the part of these officers and men on their way home. They are for the most part quiet, tired, perhaps a bit dazed at the tremendous thought of going home, perhaps a bit thoughtful at what their future in the army will be, or a bit dubious about the changes facing them in a country they left so long ago.... I envy them their going home, of course, and yet the prospect of being pushed around in replacement centers again so appalls me that I feel I should rather wait and go home with my organization, whenever that might be.

This evening and tonight we have been heading almost due W., skirting the northern coast of Sicily.

The ship is equipped with a PA system, which completely replaces the old system of ship's bells.

Steak, thick and juicy, for dinner tonight.

Military service had a way of maturing individuals far beyond their years. Men of nineteen led troops into battle as sergeants or junior officers; others only a few years older led regiments and battalions. Upon returning from leave in North Africa, Kindre recorded the strange sensation of how military service had turned him into an "old man" at twenty-three who now counseled replacements on what to expect.

May 2 [1944]

Started out about 0900 this morning. Convoy formed as we moved out totaled II ships. Water very calm. The old Samuel Griffin is plowing right along. Quarters are OK—a bunk in what's supposed to be the hospital ward-with 3 other officers. I'm the only unassigned orphan aboard. The 5 Medical companies are new overseas-arrived in Oran from the States one week ago.—on their way to somewhere in Italy.

I'm besieged constantly_-day and night—with questions by everyone from enlisted men to majors-what's it like? What have my experiences been? How is this and how is that in Italy? Etc. I feel like an old man who's been overseas for 10 years.

The food is hardly enough.—a complete breakfast at 0830, a fairly good lunch at I430, and a snack (cocoa and crackers) at 1930. 
The liberation of Rome stands as a special historical moment to many of Italian or Roman Catholic heritage. Being the first Axis city to be captured, its emancipation stood as an uplifting event in morale and spirituality. The classical beauty and historical significance of Rome made it an appropriate landmark in battling back the Allied occupation for all. For Kindre, it stood as a particularly awesome moment.

KP: You'd written about being part of the liberation of Rome. What struck you about Rome? I mean also as a romantic, it's probably one of the most romantic cities. What sticks out in terms of your memories of liberating Rome?

TK: Well, the Colosseum was the first thing I saw in Rome, and it was the night before the official parade, still under blackout conditions. [I] didn't know where we were until the clouds had parted and the moon came out and there we were right in front of the Colosseum. That was a tremendous impression. I was impressed just by, I think, the antiquity. The fact that any place of human habitation had been around that long and here was the record of it. It was absolutely fascinating and I remember just standing on one of the hills and looking at that great open space which was at one time the Circus Maximus, this huge empty field and just trying to reconstruct it from images like Ben Hur and the films.

KP: You'd had a real image of Rome and of Italy before you'd ...

TK: Oh yes. The Vatican was also tremendously impressive. I had an audience with the Pope, a small group of us. After Rome was liberated, the division special service people would arrange for small groups to have audiences, and of course I was still Catholic and the family back home were still Catholic and what you did, you went to a souvenir shop facing the square and they ... had all these medals, religious medals. You bought a whole bunch of religious medals and then you went in, when you had your audience with the Pope, you asked him to bless these. Then you had the keys of the kingdom. You send those home and my God, they were cherished.

Kindre is one of a substantial majority who never joined a veterans' organization. Like most former servicemen after leaving the military, Kindre wanted to get on with his life. Although Kindre did not reflect on the war for close to fifty years, the war had left enduring legacies both for himself and his fellow veterans.

TK: Although the military was definitely a broadening effect and I remember being particularly impressed by a lot of the guys I knew in the unit who would say things like- toward the end of the war especially we'd be talking to one another and we'd ask, "Do you think you're going to go back to Little Falls?" And the other guy would say, "Nah, I don't see how I could live there anymore." They had this world stage experience coming from a small town, and it affected lives drastically after the war. 
KP: How do you think it affected your life? You mentioned one was the ... the Italian people. Is it the way you had wanted to live?

TK: Yes.

KP: And your contact with other cultures. What other ways do you think it affected you that you can name?

TK: Well, for a number of years it made me want to put it all behind me because of the tremendous loss of life and the tremendous waste. I kept thinking of waste. I wanted to put it all behind me, and it wasn't until maybe just a few years ago that I began to look at it through different eyes.

KP: So in other words if I'd come to you twenty-five years ago and wanted to interview you on your experiences in World War II you probably wouldn't have had a great interest.

TK: I closed it all away for a number of years. I wasn't interested in war at all and of course the Korean War came along and that was another waste. The Vietnamese War I thought was dreadful on all grounds and no, I just put it all aside. I understand a lot of the DDay veterans did that too.

KP: You never joined the American Legion?

TK: No, I didn't.

KP: You really just wanted to move on.

TK: I just wanted to get it all behind me.

KP: Did the military affect you? You ended up going into a career in journalism and public relations? Did the war alter your sort of career plans at all, your thinking about careers or was it just in many ways an interruption, although a broadening experience?

TK: It was an interruption. At the end of the war, I guess it would have been in April of 1945, I remember they pulled out my record, my personnel record and because I had a degree in journalism I was asked if I wanted to try out for the position of division historian for the 34th Division. That would have fascinated me, but I wanted to go home and I knew if I applied for that and got that job I'd be there for a long, long time getting the records together and doing all the rest of it, so it was an opportunity that came a little too late. I turned it down. Then when I got home the war affected my career in that there were so few jobs in I945, because the economy hadn't really started to turn yet. The best newspaper job I could find paid $\$ 25$ a week as a general reporter and so I never really got into journalism. I had an offer of a job in Union Carbide's Public Relations Department for $\$ 45$ a week, which was big money. KP: So, you had thought of going into journalism and you still wanted to, but in a sense you couldn't afford to do that. 
TK: I couldn't afford to because I wanted to get married and so I never really became a journalist.

KP: How did the offer from Union Carbide come about?

TK: Through Rutgers.... There was a woman there, in their public relations department who was an NJC graduate, and they were looking for somebody so they sent word back to the Rutgers placement office and that's where I picked it up. It was my only really good job lead. I tried a great deal on my own and couldn't get anywhere.

KP: You did stay in the reserves until 1955. How did that come about? You didn't think of making a military career at that time? TK: No, it was strictly a matter of building credits for retirement benefits. That was the thing that everybody wanted to do. If you put in twenty years combined field service with reserve service, upon reaching age sixty you would have a military pension. At the end of the war, I already had three and a half years active service so I went into the reserve, and went to summer camp and I was a reserve a member of the 78th Division in New Jersey and met for a while in Newark, and we met for a while in New Brunswick. But, what happened after a while my career began to advance and taking that time for summer camp got to be too much of a chore. It got in the way of client needs. I was directly involved with clients and finding time for a vacation was hard enough, but the summer camp was a little too much, so I reluctantly dropped out and I remember at the time I dropped out I submitted my resignation, and I was appalled with the alacrity with which it was accepted, because there was a whole new rash of Korean War officers who were back in the reserve now, you see, and we World War II guys were old hat.

These Korean veterans would soon find themselves to be old hat with the advent of Vietnam. Although many of his classmates supported the Vietnam War, Kindre recalled his own personal opposition.

KP: You thought the Vietnam War was a waste... Did you think this initially in say ' 65 or was this later.

TK: Oh, yes. I felt it then. I felt it then. My sympathies in 1965 were entirely with the young people who were revolting against the Vietnam War. I wasn't out on the battle lines, but my sympathies were entirely with them. I felt it was a total waste of time. It was a waste of life, of energy and none of our business, really. I was on their side.

KP: You mean despite your military career?

TK: Oh yes. I couldn't see it at all.

KP: What about your colleagues? Your ... classmates and your colleagues at Hill and Knowlton, how did they feel about the war? Did you feel like you were exceptional in your views? 
TK: No, although I must say there were a lot of them that were very solidly behind the government on the Vietnam War, but there were enough that weren't so that I ...

KP: How do you think the military affected your working career, particularly at Hill and Knowlton? I think one thing from what I've gathered is your experiences with different cultures and situations. Were there any others?

TK: Well, I think that the idea of working together to accomplish a common purpose, despite all the disjointedness and the problems, I think there was something about that. That was a grand experience. This came upon me over a period of time. Right after the war, I didn't feel it, but over a period of time it did come to me. That is that the whole thing had been a tremendous enterprise and a necessary one, and at all levels it was working together. We in the ordnance company were working together. We knew what we were doing. We were supplying weapons and ammunition to keep this division going to achieve those objectives to work together to bring down the Nazis, so I think it had a big influence on me in those terms. I learned to work together with people.

In the last decade, historians have been fascinated with the way individuals and societies remember the past. The oral histories collected by the project will offer insights into how one group of Americans remembered their own experiences during the Second World War and how they viewed the conflict as a whole.

KP: I guess I wanted to ask one or two questions about the memory of war. One question is a lot has been written about the Italian campaign by historians and also there had been a number of war movies that deal with Italy. What movie do you think, if any, best reflects the Italian campaign?

TK: I remember one called "A Walk in the Sun," which I thought was very good. It captured a lot of that. The devastation and the bleakness of battle. I can't think of any others about Italy, specifically.

KP: Even World War II in general?

TK: "Two Women" with Sophia Loren, was a very powerful antiwar statement, I remember that. That was good, the Italian peasantry, very accurate.

KP: You had a very romantic vision of war, but had you seen, for example, movies like "All Quiet on the Western Front"?

TK: Oh, yes.

KP: Some have compared that of all the theaters, the Italian theater was much more like World War I than any of the other theater. Did you ever get that sense when you were there? 
TK: That's true. Well, it was more static, yes. It was much more static than any of the other theaters. It wasn't exactly trench warfare, but it was the closest to it, probably of any place in World War II. And there were a lot of morale problems caused because the motion was so slow and the cost of every inch was so high. It was tough. You didn't have any breakthroughs. It was just slog, slog, slog. KP: General Mark Clark, many military historians find him a controversial figure. What is your attitude towards Mark Clark and, in general, the leadership of the Italian campaign as a young first lieutenant? What is your thinking over time?

TK: Well, I think Mark Clark was a remote figure and I side with those who are his critics. He had a sense of history like George Patton and he operated on that level. It was said by people at that time that he was mesmerized by the idea of taking Rome from the South because Hannibal had failed to do it and he was going to become a greater general than Hannibal ... That's not much of a basis on which to make command decisions.... And what he did to the 36th Division, he decimated the 36th Division in the Rapido River battles. He just threw them in and kept them on line. They were in there for, I don't know how many days on the line until they were virtually decimated. The 36th Division after the war, I think, brought action, or tried to, against Mark Clark for having done that. I had an experience with a young second lieutenant that I brought back under guard to Casablanca (and this was in the 34th Division) because he had been under orders to hold his ground at the Rapido River and tried to advance. No one had advanced for weeks. What they did was pull one unit up after another, put them in and they'd all get shot up. Pull them out, the remnants, put another unit in. They'd all get cut up in pieces and pull them out. He was there in an untenable position and his men were all getting picked off and he couldn't go anywhere and he ordered a withdrawal and he was court martialed and given the death sentence for misbehavior in the face of the enemy. I understood perfectly what he did.

KP: Do you know what ever happened to him?

TK: No, I know he wasn't executed because Eisenhower commuted all death sentences, except one toward the end of the war. Private Slovik was his name. No, I don't know what happened to him, but he was typical, I think of the kind of push that Clark was putting on his troops. He was forcing them through sheer numbers to advance. There were no brilliant tactics or anything here....

KP: So you think his reputation as The Butcher is accurate.

TK: Yes, I think so.

At the time that Tom Kindre attended Rutgers in the late 1930s, there remained a substantial number of aged Civil War veterans still alive. Professional historians in their quest for "objectivity" ignored these impor- 
tant voices and there existed no systematic program to record them. The unique value of oral history lies in the fact that it assumes subjectivity and brushes aside claims of objectivity. In addition to hard facts, names, and numbers, oral history inserts personal opinion where objectivity once reigned. It contains an empathic quality by allowing the interviewer and the reader not only to learn what happened, but also to understand how this participant in history felt at that time and today.

Oral history is a difficult source. Its limitations lie in its uniqueness. Memories fade and opinions clash. The printed word is also hindered by its lack of true voice. But, in saving these words in an ordered fashion, it becomes possible to capture the intangible as well as the factual. Not only can the military records of veterans be preserved, but the wisdom of their personal experience through both transcription and taped recordings can be preserved as well.

The Second World War brought profound, irreversible changes to American society. Kindre is representative of those young males of European descent who entered the war with college degrees and faced frontline experience, if not actual combat. His overseas experience differed significantly from that of those who stayed on the homefront or remained in support branches of the military away from the battle zone. To emphasize the depth of diversity, Kindre's own experiences cannot be seen as representative across all the separate Army Air Corps, Navy, Marine Corps, and Coast Guard branches. Each retains its own inner military culture. No doubt, each veteran's life followed a postwar direction different from others and created by distinctive experiences.

A primary objective of the Rutgers Oral History Archives of World War II is to document, in an orderly and consistent fashion, these wartime ramifications on Rutgers' veterans and upon a larger canvas, American society itself. This will allow a convenient reference point for future historians. In conjunction with more conventional historical records, it is hoped that the project will bring a greater and more thorough understanding of the changes that American society has gone through as a direct result of the Second World War. By individualizing the different men and women of that generation and their experiences, a more encompassing and living history, one that can not be found in objective rudimentary history facts, will emerge. Unlike previous war generations, the Rutgers and Douglass World War II classes will have not just a chapter, but also a voice. 